\title{
PERANAN ORANG TUA DALAM PEMBENTUKAN KARAKTER DAN TUMBUH KEMBANG ANAK
}

\author{
Oleh \\ Luh Ayu Purnama Dewi \\ (Guru PAUD Wara Kerta Nugraha-Baha Mengwi Badung)
}

\begin{abstract}
Childhood is a very important and valuable phase and is the period of formation in the period of human formation. Early childhood is often viewed as a golden age for education providers. The golden age of the child is a very fundamental phase for the development of the individual because in this phase there are great opportunities for the formation and development of a person. So great the role of parents in the formation of character and child development, it is natural if parents need to apply a balanced parenting (authoritative) in children, not authoritarian parenting or permissive.
\end{abstract}

\section{Keywords : Role, Parent, Character, Child Growth}

\begin{abstract}
Abstrak
Masa anak merupakan suatu fase yang sangat penting dan berharga dan merupakan masa pembentukan dalam periode pembentukan manusia. Masa anak usia dini sering di pandang sebagai masa emas (golden age) bagi penyelenggara pendidikan. Masa emas anak tersebut merupakan fase yang sangat fundamental bagi perkembangan individu karena pada fase inilah terjaadi peluang yang sangat besar untuk pembentukan dan pengembangan pribadi seseorang. Begitu besarnya peran orang tua dalam pembentukan karakter dan tumbuh kembang anak, sudah sewajarnya apabila orang tua perlu menerapkan pola asuh yang seimbang (authoritative) pada anak, bukan pola asuh yang otoriter atau serba membolehkan (permissive).
\end{abstract}

\section{Kata Kunci : Peranan, Orang Tua, Karakter, Tumbuh Kembang Anak}

\section{PENDAHULUAN}

Tahun-tahun pertama kehidupan manusia merupakan periode yang sangat penting dan kritis. Keberhasilan tumbuh kembang anak di tahun-tahun pertama akan sangat menentukan hari depan anak. Kelainan atau penyimpangan apapun kalau tidak diintervensi secara dini dengan baik pada saatnya, apalagi yang tidak terdeteksi akan mengurangi kualitas sumber daya manusia kelak di kemudian hari. Untuk mencapai tumbuh kembang yang optimal tergantung pada potensi biologiknya. Tingkat tercapainya berbagai faktor yang saling berkaitan, yaitu faktor genetik, lingkungan bio-psiki-sosial dan perilaku. Lingkungan merupakan faktor yang sangat menentukan tercapai atau tidaknya potensi bawaan. Lingkungan yang cukup baik akan memungkinkan tercapainya potensi bawaan, sedangkan yang kurang baik akan menghambatnya. 
Proses yang unik dengan hasil akhir yang berbeda-beda memberikan ciri tersendiri pada setiap anak.. Untuk itu orang tua mempunyai peranan yang sangat penting dalam pembentukan karakter dan tumbuh kembang anak secara optimal. Usia 3-6 tahun merupakan periode sensitive atau masa peka pada anak yaitu suatu periode dimana suatu fungsi tertentu perlu dirangsang dan diarahkan sehingga tidak terhambat perkembangannya pendapat menurut maria Montessori (dalam Hurlock, 1978). Misalnya, masa peka untuk berbicara pada periode ini tidak terpenuhi maka anak akan mengalami kesukaran dalam berbahasa untuk periode selanjutnya. Untuk member gammbaran tentang kondisi anak pada masa ini, berikut ilustrasi tentang kemampuan bicara anak. Fahmi seorang anak berusia 3 tahun 1 bulan mengajak ibunya untuk bermain dengan mengucapkan "ma, bitinton ma!".sekilas kita tidak paham apa yang di ucapkan anak itu karena kalimatnya tidak dipahami, padahal sebenarnya fahmi mengajak ibunya untuk bermain badminton, tetapi fahmi belum dapat mengungkapkannya secara jelas. Dari ilustrasi di atas bahwa fahmi perlu dimotivasi dan di latih kemampuan berbicaranya agar dapatmenyampaikan apa yang diinginkannya dengan baik dan benar. Selain pendapat di atas Maria Montessori juga menyatakan bahwa masa sensitive anak pada usia ini mencakup sensitive terhadap keteraturan lingkungan, mengeksplorasi lingkungan dengan lidah dan tangan, sensitive untuk berjalan, sensitive terhadap objek-objek kecil dan detail, serta terhadap aspek - aspek social kehidupan.
Masa anak merupakan suatu fase yang sangat penting dan berhaga, dan merupakan masa pembentukan dalam periode pembentukan manusia menurut Froebel (roopnaire,J.E., 1993). Masa anak usia dini sering di pandang sebagai masa emas ( golden age ) bagi penyelenggara pendidikan. Masa emas anak tersebut merupakan fase yang sangat fundamental bagi perkembangan individu karena pada fase inilah terjaadi peluang yang sangat besar untuk pembentukan dan pengembangan pribadi seseorang. Menurut Froebel jika orang dewasa mampu menyediakan suatu "tanam" yang dirancang sesuai dengan potensi dan bawaan anak maka anak akan berkembang secara wajar.

Pandangan lain tentang anak diajukan oleh kelompok konstruktivis yang di motori Jean Piaget dan Lev Vygotsky. Menurut meereka anak bersifat aktif dan memiliki kemampuan untuk membangun pengetahuanya, secara mental anak menkontruksi pengetahuannya melalui refleksi terhadap pengalamannnya. Anak memperoleh pengetahuan bukan dengan cara menerima secara passif dari orang lain, melainkan dengan cara membangun pengetahuannya sendiri secara aktif melalui interaksi dengan lingkungannya. Anak adalah makhluk belajar aktif yang dapat mengkreasi dan membangun pengetahannya.

Dalam kehidupan sehari-hari dapat kita saksikan anak tidak takut untuk mencoba dan menemukan sesuatu.Apabila anak sedang bermain pasir,anak akan terus mencoba memasukkan pasir dari satu tempat ke tempat lain. Apabila pasir di satu tempat penuh ia akan menumpahkannya dan mengisinya kembali. Aktifitas seperti 
it uterus diulang seolah anak tidak lelah melakukannya. Ketika bermain seperti itu anak mencoba mengamati dan membangun pengetahuannya sendiri.

Anak merupakan aset yang menentukan kelangsungan hidup, kualitas dan kejayaan suatu bangsa di masa mendatang. Oleh karena itu anak perlu dikondisikan agar dapat tumbuh dan berkembang secara optimal dan dididik sebaik mungkin agar di masa depan dapat menjadi generasi penerus yang berkarakter serta berkepribadian baik. Keluarga adalah lingkungan yang pertama dan utama dikenal oleh anak. Karenanya keluarga sering dikatakan sebagai primary group. Alasannya, institusi terkecil dalam masyarakat ini telah mempengaruhi perkembangan individu anggota-anggotanya, termasuk sang anak. Kelompokinilah yang melahirkan individu dengan berbagai bentuk kepribadiannya di masyarakat. Oleh karena itu tidaklah dapat dipungkiri bahwa sebenarnya keluarga mempunyai fungsi yang tidak hanya terbatas sebagai penerus keturunan saja. Mengingat banyak hal-hal mengenai kepribadian seseorang yang dapat dirunut dari keluarga (Mardiya, 2000 : 10). Akibat pengaruh globalisasi yang makin menguat di setiap aspek kehidupan, banyak bangsa-bangsa di dunia yang tidak berkarakter kehilangan jati dirinya. Tanpa di sadari budaya telah mengalami pergeseran (akulturasi). Semula batas budaya barat dan timur terlihat jelas, namun sekarang ini yang terjadi budaya luar secara permisif berbaur dengan budaya lokal. Kondisi yang demikian menjadi berbahaya takala budaya buruk dari luar ditelan mentah-mentah oleh anak-anak dalam sebuah keluarga. Seperti budaya kekerasan, minum minuman keras, penyalahgunaan narkoba atau seks bebas. Disinilah peran orang tua ditantang untuk mampu mengembalikan karakter anak dalam kapasitas agar anak dapat tumbuh dan berkembang sebaik-baiknya. Prilaku social merupakan aktivitas dalam berhubungan dengan orang lain, baik dengan teman sebaya,guru, orang tua, saudaranya ,maupun alak komunikasi yang jaman sekarang sudah semakin canggih seperti internet.

\section{PEMBAHASAN}

\subsection{Tumbuh Kembang Anak}

Sebuah Realitas. Sejak dilahirkan ke dunia setelah bersemayam dalam kandungan selama 9 bulan 10 hari, anak memliki ciri khusus yang membedakan dari orang dewasa, yakni terus tumbuh dan berkembang (Sunartini, 2001: 1). Tumbuh kembang anak sebenarnya sudah dimulai sejak pembuahan (konsepsi) sampai anak dewasa (kira-kira umur 21 tahun). Jadi tumbuh kembang ini merupakan suatu proses yang panjang dari satu sel menjadi berjuta sel manusia. Pertumbuhan dan perkembangan anak secara prinsip dapat dibagi dalam 4 periode, yaitu masa balita, pra sekolah, masa pertengahan kanak-kanak dan masa renaja. (Herini Sarminto, 2004: 1). Periode penting dalam tumbuh kembang anak adalah masa balita, karena pada masa ini terjadi pertumnuhan dan perkembangan dasar yang akan memperngaruhi perkembangan selanjutnya.

Pertumbuhan anak ditunjukkan dengan bertambahnya tinggi dan berat badan, lingkar kepala, lingkar lengan atas, lingkar dada, dan sebagainya, Pertumbuhan anak ditunjukkan dengan 
faktor gizi dan nutrisi. Sementara perkembangan anak ditunjukkan dengan perkembangan psikomotor, perkembangan mental dan intelektual, perkembangan sosial, kemampuan komunikasi, perilaku dan perkembangan seksual. Perkembangan anak ini akan dipengaruhi oleh faktor bawaan dan lingkungan (Hibana S. Rahman, 2002 :37) Menurut Herini Sarminto (2004 : 2) faktor bawaan (genetik) merupakan faktor yang dibawa anak sejak lahir. Faktor bawaan ini merupakan modal dasar dalam mencapai hasil akhir proses tumbuh kembang anak. Potensi bawaan yang bermutu bila dapat berinteraksi dengan lingkungan secara positif akan diperoleh hasil akhir yang optimal. Sementara faktor lingkungan merupakan faktor diluar individu.

Lingkungan ini merupakan lingkungan bio-fisika-psiko-sosial yang mempengaruhi individu setiap hari, mulai dari konsepsi sampai akhir hayatnya. Secara garis besar faktor lingkungan ini dibagi menjadi dua yaitu : (1) Lingkungan anak sebelum anak lahir, misalnya gizi ibu, obat-obatan, penyakit ibu, stress, posisi janin, gangguan hormon, radiasi, infeksi dan sebagainya; (2) Posisi setelah anak lahir, misalnya gizi anak, penyakitpenyakit, gangguan hormon, perumahan, kebersihan, stimulasi, stress, kasih sayang, stabilitas rumah tangga dan adat istiadat. Terkait dengan tumbuh kembang anak para ahli psikologi perkembangan sepakat bahwa usia balita adalah "The Golden Age" atau masa emas dalam tahap perkembangan hidup manusia. Dikatakan sebagai masa emas karena pada masa ini tidak kurang 100 milyar sel otak siap untuk distimulasi agar kecerdasan seseorang dapat berkembang secara optimal dikemudian hari. Dalam banyak penelitian menunjukkan kecerdsan anak usia 0-4 tahun terbangun $50 \%$ dari total kecerdasan yang akan dicapai pada usia 18 tahun. Hal ini menunjukkan bahwa usia 4 tahun pertama adalah masa-masa paling menentukan dalam membangun kecerdasan anak dibanding masa-masa sesudahnya. Artinya bila pada usia tersebut tidak mendapat rangsangan yang maksimal maka potensi tumbuh kembang anak tidak akan teraktualisasikan secara optimal. Disamping itu bukan tidak mungkin bila pada masa ini anak tidak dapat mengalami gangguan perkembangan emosi, sosial, mental, intelektual dan moral sangat menentukan karakter cara bersikap dan pola perilakunya (Anik Rahmani Yudhastawa, 2005 : 10).

\subsection{Hak Anak}

Membicarakan kelangsungan hidup dimuka bumi ini adalah membicarakan manusia, karena manusia merupakan makhluk paling dominan dalam kehidupan dan lebih khusus untuk kelangsungan hidup masa dengan tergantung pada anak sebagai generasi penerus. Anak merupakan bagian dari generasi muda, penerus citacita dan perjuangan bangsa. Disamping itu anak merupakan sumber daya manusia yang perlu mendapatkan perhatian dan perlindungan dari berbagai ancaman dan gangguan agar supaya hak-haknya tidak terabaikan. (Sri Sugiharti, 2005: 1) Tentang apa saja hak anak, Perserikatan Bangsa-Bangsa telah mengeluarkan resolusi No. 44/25 tentang konvensi hakhak anak (Convention on the Rights of the Child) tertanggal 20 November 1989. Konvensi ini telah diratifikasi Indonesia pada tanggal 25 Agustus 1990 dengan 
keputusan presiden nomor 36 tahun 1990. sekarang ini Indonesia sudah mempunyai UU No. 23 Tahun 2002 tentang perlindungan anak yang didalamnya memuat 4 hak dasar anak yaitu:

1. Hak untuk memperoleh keberlangsungan hidup

2. Hak untuk tumbuh dan berkembang

3. Hak untuk berpartisipasi

4. Hak untuk memperoleh perlindungan

Menurut Noor Siswanto (2002:5) secara lebih terinci ada sebelas hak yang dimiliki oleh anak antara lain: (1) hak untuk didaftar sejak kelahirannya, hak atas nama, memperoleh kewarganegaraan dan sejauh mungkin mengetahui dan dipelihara oleh orang tuanya; (2) hak mempertahankan identitas; (3) hak tidak dipisahkan dengan orang tua; (4) hak berhubungan dengan orang tua; (5) hak menyatakan pendapat, kemerdekaan berpikir, beragama; (6) hak kemerdekaan berserikat dan berkumpul; (7) hak memperoleh bantuan khusus dari negara bagi anak yang kehilangan lingkungan keluarga; (8) hak menikmati norma kesehatan tertinggi dan hak memperoleh pendidikan; (9) hak memperoleh pemeliharaan, perawatan serta perlindungan; (10) hak untuk beristirahat, bersantai, bermain dan hak untuk turut serta dalam kegiatan rekreasi dan; (11) hak untuk dilindungi dari eksploitasi ekonomi, eksploitasi seksual dan kegiatan yang bersifat pornografis serta pemakaian narkoba. Hak-hak anak tersebut perlu diwujudkan agar tumbuh kembang anak dapat berlangsung optimal. Dengan adannya hak-hak tersebut sudah barang tentu menjadi kewajiban keluarga, masyarakat dan bangsa (termasuk didalamnya institusi pendidikan) untuk memenuhinya. Keberhasilan bangsa ini dalam mencetak generasi yang berkwalitas menurut Sri Mirmaning Tyas (2005:10) sesungguhnya tidak dapat hanya disandarkan pada institusi pendidikan semata. Peran masyarakat luas, keluarga besar, pemerintah, swasta, dunia bisnis hingga orang tua sendiri perlu dimaksimalkan. Mendasarkan pada hak dasar anak maka hak yang paling sering diabaikan adalah hak partisipasi anak dalam menentukan arah perkembangan dirinya. Orang dewasa, guru, orang tua, pendidik seringh kali merasa lebih berhak menentukan apa yang terbaik bagi anak tanpa mempertimbangkan basis karakter anak. Sehingga yang terjadi kemudian amat banyak orang tua yang "Gagal" didik sejak kecil itu, melahirkan anakanak yang "Gagal” seperti dirinya.

\subsection{Membangun Karakter Anak}

Membangun karakter berarti mendidik. Untuk berpikir tentang pendidikan dapat kita mudahkan dengan membuat analogi sebagaimana seorang petani yang hendak bertanam di ladang. Anak yang akan dididik dapat diibaratkan sebagai tanah, isi pendidiklah sebagai bibit atau benih yang hendak ditaburkan, sedangkan pendidik diibaratkan sebagai petani. Untuk mendapatkan tanaman yang bagus, seorang petani harus jeli menentukan jenis dan kondisi lahan, kemudian menentukan jenis bibit yang tepat, serta cara yang tepat, setelah mempertimbangkan saat yang tepat pula untuk menaburkan bibit. Setelah selesai menabur, petani tidak boleh diam, tetapi harus memelihara, danmerawatnya jangan sampai kena hama pengganggu (Suharsimi Arikunto 2004:1). 
Membangun karakter anak, yang tidak lain adalah mendidik kejiwaan anak, tidak semudah dan sesederhana menanam bibit. Anak adalah aset keluarga, yang sekaligus aset bagsa. Membesarkan fisik anak, masih dapat dikatakan jauh lebih mudah dengan mendidik ajiwa karena pertumbuhanya dapat dengan langsung diamati, sedangkan perkembangan jiwa hanya diamati melalui pantulannya.

Menurut Oppenheim (dalam Suharsimi Arikunto, 2004 : 2) karakter atau watak seseorang dapat diamati dalam dua hal, yaitu sikap (attitude) dan perilaku (behavior). Jadi sikap sesorang termasuk anak-anak, tidak dapat diketahui apabila tidak ada rangsangan dari luar. Rangsangan itu sendiri dipengaruhi oleh beberapa faktor anatara lain cara menyampaikan, waktu terjadinya, pemberian rangsangan dan cara memberikan rangsangan. Dengan demikian maka pemebntukan sikap yang selanjutnya merupakan pembetuk karekter atau watak anak, juga sangat tergantung dari rangsangan pendidikan yang diberikan oleh pendidik.

Banyaknya anak yang terlibat dalam tindak kenakalan anak baik berupa tindak kekerasan, penipuan, pemerkosaan/ pelecehan seksual, pencurian, perampokan hingga pembunuhan serta tindakan/perilaku yang negatif lainnya seperti mabuk-mabukan, merokok atau menyalahgunakan narkoba, merupakan salah satu bentuk gagalnya pendidikan terhadap anak. Era globalisasi memang telah mengubah segalanya. Beratnya persaingan hidup telah menyebabkan orang lupa memperhatikan kebutuhn anak karena sibuk mencari nafkah. Sementara perkembangan teknologi informasi dan komunikasi telah menyebabkan budaya luar baik atau buruk mengalir bagitu derasnya. Dampaknya bila tidak ada pengawasan dan bimbingan yang cukup buruk dari luar.

Oleh karenanya, sejak dini pada anak perlu ditanamkan nailai-nilai moral sebagai pengatur sikap dan perilaku individu dalam melakukan interaksi sosial di lingkungan keluarga, masyarakat maupun bangsa (Gunarwan, 2005 : 10). Terdapat tiga teori perkembangan yang diyakini menentukan hasil jadi seorang anak. Pertama, teori tabula rasa, yakni teori yang menyatakan bahwa hasil jadi seorang anak sangat ditentukan seperti apa dia dididik. Teori ini mengibaratkan anak sebagai kertas putih yang kosong, tergantung siapa yang menulis dan melukisnya. Menulis dengan rapi atau dengan mencoret- coret bahkan diremas hingga kumal. Semua tergantung yang memegang kandali atas kertas putih tersebut. Kedua, teori genotype, yang menyatakan bahwa hasil akhir seorang anak sangat ditentukan oleh gen (sifat, karakter, biologis) orang tuanya. Pepatah sering mendukung teori ini dengan perumpamanaan : air hujan mengalir tak jauh dari atapnya. Sifat kareakter, hingga yang lebih ekstrim lagi nasib anak-anak dianggap tidak akan jauh dari situasi orang tuanya. Penganut paham ini sangat kenatar jika sampai pada keputusan menentukan jodoh anakanaknya. Orang tuanya cocok, maka hubungan anaknya boleh berlanjut, namun jika tidak cocok maka biasanya orang tua tidak akan memberi restu hubungan anaknya. Ketiga, teori gabungan yang menggabungkan 2 karakter di atas di tambah denagn faktor mileu (lingkungan ). 
Teori ini banyak dipakai oleh para psikolog maupun pengembang pendidikan. Teori ini meyakini bahwa hasil akhir seorang anak ditentukan oleh tiga hal: faktor orang tua, faktor pendidkan dan faktor lingkungan. Banyak faktor lingkungan yakni dengan siapa dia bergaul, bergaul, pengaruh orangorang dekat, paling diyakini sangat efektif mempengaruhi perkembangan anak Membangun karakter anak dengan demikian dibutuhkan upaya serius dari berbagai pihak terutama keluarga untuk mengkondidikan ketiga faktor di atas agar kondusif untuk tumbuh kembang anak. Pendidikan karakter pada anak harus siarahkan agar anak memiliki jiwa mandiri, bertanggung jawab dan mengenal sejak dini untuk dapat membedakan hal yang baik dan buruk, benar-salah, hakbatil, angkara murka-bijaksana, perilaku hewani dan manusiawi (Witono, 2005:1)

\subsection{Peran Orang Tua}

Anak adalah individu yang unik. Banyak yang menagatkan bahwa anak adalah miniatur dari orang dewasa. Padahal mereka betulbetul unik. Mereka belum banyak memiliki sejarah masa lal. Pengalaman mereka sangat terbatas. Di sinilah peran orang tua yang memiliki pengalaman hidup lebih banyak sangat dibutuhkan membimbing dan mendidik anaknya. Apabila dikaitkan dengan hakhak anak, menurut Sri Sugiharti (2005:1) tugas dan tanggung jawab orang tua antara lain :

1. Sejak dilahirkan mengasuh dengan kasih sayang.

2. Memelihara kesehatan anak.

3. Memberi alat-alat permainan dan kesempatan bermain.
4. Menyekolahkan anak sesuia dengan keinginan anak.

5. Memberikan pendidikan dalam keluarga, sopan santun, sosial, mental dan juga pendidikan keagamaan serta melindungi tindak kekerasan dari luar.

6. Memberikan kesempatan anak untuk mengembangkan dan berpendapat sesuai dengan usia anak.

Atas dasar itu orang tua yang bijaksana ankan mengajak anak sejak dini untuk berinteraksi denagn lingkungan sekitar. Saat itulah pendidikan karakter diberikan. Mengenal anak akan perbedaan di selilingnya dan diliatkan dalam tanggung jawab hidup sehari-hari, merupakan sarana anak untuk belajar menghargai perbedaan di sekelilingnya dan mengembangkan karakter di tengah berkembangnya masyarakat. Pada tahap ini orang tua dapat mengajarkan nialinilai universal seperti cara menghargai orang lain, berbuat adil pada diri sendiri dan orang lain, bersedia memanfaatkan orang lain.

Bapak ibu sebagai orang tua anak, adalah contoh keteladanan dan perilaku bagi anak. Oleh karena itu orang tua harus berperilaku baik, saling asih, asah dan asuh. Ibu yang secara emosional dan kejiwaan lebih dekat dengan anaknya harus mampu menjadi teladan yang baik bagi anak-anaknya baik dalam bertutur kata, bersikap maupun bertindak. Peran ibu dalam pembentukan karakter ini demikian besar, sehingga ada pepatah yang mengatakan bahwa "Wanita adalah tiang negara. Manakala wanitanya baik maka baiklah negara. Manakala wanitanya rusak, maka rusaklah negara". 
Sementara itu sang bapak sebagai kepalakeluarga juga harus mampu menjadi teladan yang baik. Karena ayah yang terlibat hubungan dengan anaknya sejak awal akan mempengaruhi perkembangan kognitif, motorik, kemampuan, menolong diri sendiri, bahkan meningkatkan kemampuan yang lebih baik darianak lain. Kedekatan dengan ayah tentunya juga akan mempengaruhi pembentukan karakter anak. Begitu besarnya peran orang tua dalam pembentukan karakter dan tumbuh kembang anak, sudah sewajarnya apabila orang tua perlu menerapkan pola asuh yang seimbang (authoritative) pada anak, bukan pola asuh yang otoriter atau serba membolehkan (permissive).

Pola asuh yang seimbang (authoritative) akan selalu menghargai individualitas akan tetapi juga menekankan perlunya aturan dan pengaturan. Mereka dangat percaya diri dalam melakukan pengasuhan tetapi meraka sepenuhnya mengahrgai keputusan yang diambil anak, minat dan pendapat serta perbedaan kepribadiannya. Orang tua dengan pola asuh model ini, penuh dengan cinta kasih, mudah memerinci tetapi menuntut tingkah laku yang baik. Tegas dalam menjaga aturan bersedia memberi hukuman ringan tetapi dalam situasi hangat dan hubungan saling mendukung. Mereka menjelaskan semua tindakan dan hukuman yang mereka lakukan dan minta pendapat anak. Anak dari orang tua yang demikian akan merasa tenang dan nyaman. Mereka akan menajdi paham kalau mereka disayangi tetapi sekaligus mengerti terhadap apa yang diharapkan dari orang tua. Jadi anak sejak pra sekolah akan menunjukkan sikap lebih mandiri, mampu mengontrol dirinya, biasa bersikap tegas dan suka eksplorasi. Kondisi yeng demikian itu tidak akan didapatkan anak bila orang tuanya menerapkan pola asuh otoriter atau permisif. Karena anak-anak di bawah asuhan otoriter akan menjadi pendiam, Penakut dan tidak percaya pada diri mereka sendiri. Sementara anak-anak yang diasuh dengan model permisif akan menajdi anak yang tidak mengenal aturan dan norma serta idak memiliki rasa tanggung jawab. Dengan berkaca pada kondisi saat ini, sudah saatnya orang tua sekarang mengambil peran lebih untuk mengembangkan karakter dan memberi kesempatan untuk tumbuh dan berkembang secara optimal agar anak menjadi manusia berkualitas.

\section{SIMPULAN}

Keluarga adalah lingkungan yang pertama dan utama dikenal oleh anak, jadi dalam lingkungan keluargalah watak dan kepribadian anak akan dibentuk yang sekaligus akan mempengaruhi perkembangannya di masa depan. Di mata anak, orang tu (ayah ibu) adalah figur atau contoh yang akan selalu ditiru olehanak-anaknya. Olehsebabitu, ayahibu harus mampu memberi contoh yang baik pada anak-anaknya, memberi pengasuhan yang benar serta mencukupi kebutuhankebutuhannya dalam batasan yang wajar. Dengan memainkan peranan yang benar dalam mendidik dan mengasuh anak, anak akan tumbuh dan berkembang secara optimal. Dan yang tidak kalah pentingnya, anak akan tumbuh menjadi anak yang berkarakter tidak mudah larut oleh budaya buruk dari luar serta menjadi anak yang berkepribadian baik sebagai aset generasi penerus bangsa di masa depan. 


\section{DAFTAR PUSTAKA}

Ernawulan syaodin mubiar agustin "buku bimbingan konseling untuk anak usia dini " penerbit universitas terbuka, tahun 2012.

h t t p s : / / m a r d i a w ordpres s . com/2009/10/25/perananorangtua dalampembentukankarakterdan tumbuhkembanganak/ 